\title{
$1: 27634715-27622953$
}

National Cancer Institute

\section{Source}

National Cancer Institute. 1: 27634715-27622953. NCI Thesaurus. Code C42275.

Physical location of FGR_Gene 